\title{
MYOCARDIAL INFARCTION DIAGNOSIS AND CARDIAC TROPONINS
}

\author{
Berra Kurtoğlư ${ }^{1}$, Burcu Erkılıç², Dilay Yağmur Gürsel ${ }^{2}$, Gülsüm Arslan², Ogün Bacaksızoğlu², Pınar Altundal ${ }^{2}$, \\ Selin $\mathrm{Kara}^{2}$, Yasemin Ardıçoğlu ${ }^{3}$
}

\author{
${ }^{1}$ Gazi University School of Medicine, Ankara, TURKEY \\ 2 TOBB University of Economics and Technology School of Medicine, Ankara, TURKEY \\ ${ }^{3}$ Department of Medical Biochemistry, TOBB University of Economics and Technology School of Medicine, \\ Ankara, TURKEY
}

\begin{abstract}
Acute myocardial infarction is a condition that develops due to the blockage of blood flow to the heart. Serial electrocardiography follow-up should be performed in patients with suspected acute myocardial infarction, serum cardiac troponin levels should be measured, and this measurement should be repeated at regular intervals. Cardiac troponins are the main markers for the diagnosis of acute myocardial infarction, as they are sensitive and specific biochemical markers of myocardial cell necrosis. Elevated levels of cardiac troponins indicate cardiac damage, but it does not explain the cause of the damage. Increases in cardiac troponin levels can be observed in many different disease states and do not necessarily indicate acute myocardial infarction. It is necessary to check cardiac troponin levels in a patient admitted to the hospital in order to exclude other diseases before establishing the diagnosis of myocardial infarction. The one-hour "rule-in" and "rule-out" algorithms are used in the tests performed on patients who come to the emergency department with non-ST elevation myocardial infarction. In addition, there are point-of-care cardiac troponin tests that can be used in emergency services and ambulances. However, while using point-of-care cardiac troponin tests for the diagnosis of myocardial infarction, it should be kept in mind that these tests are less sensitive and more costly than tests performed in central laboratories. Keywords: Myocardial infarction, acute coronary syndrome, troponin
\end{abstract}

\section{INTRODUCTION}

Cardiac troponins (cTn) are cardiospecific markers of ischemic myocardial damage that are used in the diagnosis of acute coronary syndrome (ACS) and the clinical diagnosis of myocardial injuries with different etiology and pathogenesis $(1,2)$.

As a result of the acceleration of biochemistry studies, the importance of cardiac troponins in the diagnosis of acute myocardial infarction (AMI) has been understood. Compared to other markers, it is tissue-specific and gives rapid results, which has led academic studies to focus on cardiac troponins (3).

\section{CARDIAC TROPONINS}

Cardiac troponins regulate the calcium-dependent interaction of actin and myosin and play a role in myocardial contraction. There are 3 subforms of cTn: cTnT, cTnI, and cTnC (4).

\section{Structural Differences}

When we examine the structural differences between cTns, there are 2 serine amino acids at the amino-terminal end of cTnI. These amino acids induce a cyclic adenosine monophosphate (cAMP) dependent phosphorylation. This situation reduces the affinity of cTnC to calcium. The reason for the low cardiac specificity of cTnC is its similar structure with its isoform which is found in skeletal muscle. However, the cardiac specificities of cTnT and cTnI are quite high. The reason for this is that they are encoded by genes different from the genes encoding their isoforms in skeletal muscle (4).

\section{Functions}

Cardiac troponins are sensitive and specific biochemical markers of myocardial cell necrosis. Even small damages in the myocardium can be detected by 
Table 1: Basic information on cardiac troponins. Table reprinted from reference (1).

$$
\text { cTnI cTnT }
$$

\begin{tabular}{|c|c|c|}
\hline Source in the body & Myocardium & Myocardium \\
\hline $\begin{array}{c}\text { Molecular Weight } \\
\text { (Dalton) }\end{array}$ & 23.876 & 37.000 \\
\hline Biological half life & $<120$ & 120 \\
\hline $\begin{array}{l}\text { Maximum } \\
\text { concentration in the } \\
\text { blood (hours) }\end{array}$ & $12-30$ & $12-75$ \\
\hline $\begin{array}{l}\text { Persistence in blood } \\
\text { (days) }\end{array}$ & $4-7$ & $4-12$ \\
\hline Kidney elimination & Happens & Does not happen \\
\hline $\begin{array}{l}\text { Increase after AMI } \\
\text { (hours) }\end{array}$ & $3-5$ & $3-4$ \\
\hline $\begin{array}{c}\text { Applicability for ACS } \\
\text { diagnosis }\end{array}$ & Similar & Similar \\
\hline $\begin{array}{l}\text { Efficiency in } \\
\text { cardiovascular risk } \\
\text { classification }\end{array}$ & Similar & Similar \\
\hline $\begin{array}{l}\text { Biphasic waveform } \\
\text { during successful and } \\
\text { early reperfusion }\end{array}$ & Less separator & Separator \\
\hline $\begin{array}{l}\text { Applicability for } \\
\text { reperfusion assessment }\end{array}$ & Happens & Happens \\
\hline Reinfarction diagnosis & $\begin{array}{l}\text { Limited use due to long } \\
\text { term persistence in the } \\
\text { blood }\end{array}$ & $\begin{array}{l}\text { Limited use due to long- } \\
\text { term persistence in the } \\
\text { blood }\end{array}$ \\
\hline $\begin{array}{l}\text { Increase in patients with } \\
\text { stage } 5 \text { chronic kidney } \\
\text { disease (National } \\
\text { Kidney Foundation) }\end{array}$ & Less separator & Separator \\
\hline $\begin{array}{l}\text { Maximum limit of } \\
\text { upper reference limit }\end{array}$ & $300 x$ & $300 x$ \\
\hline $\begin{array}{l}\text { AMI focal size } \\
\text { estimation }\end{array}$ & Happens & Does not happen \\
\hline $\begin{array}{c}\text { Sampling timing for } \\
\text { diagnosing AMI (CSCB, } \\
\mathbf{2 0 0 8 )}\end{array}$ & $\begin{array}{l}\text { 6-9 hours upon arrival, } \\
12-24 \text { hours if negative }\end{array}$ & $\begin{array}{l}6-9 \text { hours upon arrival, } \\
12-24 \text { hours if negative }\end{array}$ \\
\hline
\end{tabular}

cTnI: Cardiac troponin I. cTnT: Cardiac troponin T AMI: Acute myocardial infarction ACS: Acute coronary syndrome. 
troponin measurements with high sensitivity (5). Cardiac troponins are used for the diagnosis of cardiovascular diseases due to myocardial necrosis and to evaluate the possibility of worsening prognosis (Table 1) (1).

For the early period, cTn sensitivity is higher than creatine kinase-MB (CK-MB). The reason for this is the presence of 13-15 times more cTn in the myocardium than the amount of CK-MB per gram $(6,7)$. Both the American College of Cardiology (ACC) and the European Society of Cardiology (ESC) recommend cTn as a biochemical marker for the diagnosis of AMI for these reasons $(8,9)$.

The specificity of cTn is high for the diagnosis of coronary ischemia. In addition, levels may increase in clinical conditions such as acute and chronic heart failure, cardiac contusion, cardioversion, pacing, ablation, endomyocardial biopsy, and hypertensive crisis (10). Furthermore, ACC and the American Heart Association determined that $\mathrm{cTn}$ can be used as a marker in the prognosis of unstable angina pectoris (11-13). Morbidity, mortality, and incidence in clinical pictures such as arrhythmia, ACS, pulmonary embolism, and stroke were examined and cTnT was observed to be a better marker in terms of showing the long-term mortality risk after an AMI (14).

It is necessary to exclude other diseases by examining cTns before reaching the final diagnosis of MI. A detailed history and physical examination of the patient are necessary to accurately identify the underlying cause, especially in small increases in serum cTn levels (15).

\section{DIAGNOSTIC VALUE OF TROPONINS IN THE DIAGNOSIS OF ACS AND AMI}

Acute myocardial infarction (AMI) is a condition that develops due to the blockage of blood flow to the heart (16). It is the coronary arteries that supply oxygen and nutrients to the heart. If the blood flow is interrupted in these arteries, the necessary oxygen, and nutrients cannot be provided, resulting in heart damage. If this situation develops suddenly, it is defined as AMI. However, when these arteries are partially obstructed, the amount of blood flow decreases, and a chest pain called angina occurs. This situation is an indicator of MI (17).

Clinically, ACS is a group of diseases that result in acute myocardial ischemia. ACS is a term that includes patients who have signs of acute myocardial ischemia, unstable angina pectoris, and MI with or without ST-segment elevation (18). The main objectives of the physician who encounters a patient with ACS are as follows: Keeping the left ventricular functions in place by minimizing myocardial cell death in the patient with MI and preventing the occurrence of heart failure to eliminate acute and life-threatening symptoms such as ventricular fibrillation/pulseless ventricular tachycardia, symptomatic bradycardia, unstable tachycardia (12).

In AMI; pressure, tightness, pain, or squeezing sensation radiating to the chest, arm, neck, jaw, or back; nausea, indigestion, heartburn or abdominal pain, shortness of breath, cold sweat, fatigue, and sudden dizziness are the signs and symptoms expected to be seen in the patient (16). While constant pain is being observed in $80 \%$ of the patients, the pain is observed in an accelerated manner in $20 \%$. In another aspect, the incidence of atypical clinical pictures in ACS cases are also quite high. These atypical clinical scenarios are commonly seen in the young (25-40 years old), elderly (>75 years old), female patients, and in the patients with a history of diabetes (19). In patients with longterm diabetes history, the patient may not feel pain as a result of the effect of diabetes on the patient's nerves (17). In particular, pain during rest, epigastric pain, acute digestive disorders, stabbing chest pain, chest pains with some pleuritic features, or worsening dyspnea are atypical symptoms of unstable angina. Consequently, a reliable determination cannot be made in the diagnosis of AMI by assessing solely the character of the pain (19).

During the physical examination, most patients show signs of autonomic nervous system activation (sweating, pallor), hypotension, or conditions similar to a narrowed pulse pressure range. In addition, irregular heart rate, bradycardia or tachycardia, third heart sound, or basal rales may be encountered. The main purpose of physical examination is to eliminate non-cardiac conditions that may cause angina, cardiac diseases such as pericarditis, valvular diseases without ischemia, potential non-cardiac triggers, and pneumothorax in diagnosis; to examine left ventricular dysfunction and potential causes of hemodynamic instability (19).

\section{In Patients With Suspected Acute Ischemic Myo- cardial Damage (19):}

At rest, electrocardiography (ECG) should be taken and monitored continuously (The first ECG allows a correct diagnosis rate of only $50 \%$. Therefore, serial ECG follow-up should be done especially during the patient's complaints.). 
Cardiac troponin $\mathrm{T}(\mathrm{c} T n \mathrm{~T})$ or cardiac troponin I (cTnI) values should be measured at the first examination of the patient, and if normal values are observed, these measurements should be repeated at regular intervals.

Even though myocardial infarction (MI) can be diagnosed by symptoms, electrocardiographic abnormalities, elevated biomarkers of myocardial necrosis, and imaging such as echocardiography (ECHO); the patients without abnormal ECG, ECHO, and the patients who do not present with chest pain should be considered in terms of MI $(20,21)$.

Due to the similarity of symptoms and inconclusive ECG findings, several prominent international cardiac associations have made a universal definition of $\mathrm{MI}$ in 2012. According to this definition, "detection of a rise and/or fall of cardiac biomarker values, preferably cardiac troponin, with at least one value above the 99th percentile upper reference limit and at least one other diagnostic indicator such as wall motion abnormality that can be seen through imaging" is required for the diagnosis of MI (22).

Before the development of cardiac troponin sensors, only the electrocardiogram was used to diagnose acute myocardial infarction, and it was commonly misdiagnosed. Following the discovery of the significant correlation between the cardiac troponin levels and the onset of the AMI, cTnT and cTnI were used to diagnose AMI by detecting their levels in blood by using immunological assays with a recommended turnaround time of less than 1 hour by the National Academy of Clinical Biochemistry (23-25). Afterward, in Germany, faster techniques such as cTnT rapid strip tests were developed based on a sandwich enzyme-linked immunosorbent assay (ELISA), but this test was used for the patients who were already diagnosed with AMI (26).

In comparison between troponins, some studies in the literature stated that, among two cardiac enzymes, serum cTnT level has significantly higher sensitivity in the diagnosis of MI, whereas serum cTnI level has higher specificity (Table 2) (27-30).

Table 2: Comparison of cardiac troponins.

\begin{tabular}{|c|c|c|c|c|c|}
\hline Study & $\begin{array}{l}\text { Cardiac } \\
\text { troponin }\end{array}$ & Test & $\begin{array}{c}\text { Critical } \\
\text { value } \\
(\mathrm{ng} / \mathrm{mL})\end{array}$ & $\begin{array}{l}\text { Specificity } \\
(\%)\end{array}$ & $\begin{array}{c}\text { Sensitivity } \\
(\%)\end{array}$ \\
\hline \multirow{2}{*}{$\begin{array}{c}\text { Avcıküçük et al. } \\
\text { (27) }\end{array}$} & $\mathrm{cTnT}$ & Roche & $>0.03$ & 70 & 92 \\
\hline & $\mathrm{cTnI}$ & $\begin{array}{c}\text { Siemens } \\
\text { Dimension }\end{array}$ & $>0.017$ & 90.9 & 80 \\
\hline \multirow{2}{*}{$\begin{array}{l}\text { Pagani et al. } \\
\text { (28) }\end{array}$} & $\mathrm{cTnT}$ & Roche & $>0.03$ & 68.1 & 98 \\
\hline & cTnI & Beckman & $>0.04$ & 78.7 & 100 \\
\hline \multirow{2}{*}{$\begin{array}{l}\text { Elmali et al. } \\
\text { (29) }\end{array}$} & $\mathrm{cTnT}$ & Roche & $>0.03$ & 91 & 63 \\
\hline & cTnI & Beckman & $>0.04$ & 92 & 63 \\
\hline \multirow{2}{*}{$\begin{array}{l}\text { Ross et al. } \\
\quad(30)\end{array}$} & cTnT & - & - & - & - \\
\hline & $\mathrm{cTnI}$ & $\begin{array}{l}\text { Siemens } \\
\text { Status II } \\
\text { Analyzer }\end{array}$ & $>0.6$ & 81 & 94 \\
\hline
\end{tabular}

cTnT: Cardiac troponin T cTnI: Cardiac troponin I. 
Hemolyzed samples are one of the most important sources of preanalytical error. In the measurements made with hemolyzed sera, cTn values were found lower than they were supposed to be. Another source of error is biotin interaction. False high results of troponin values are seen in blood samples of patients who take too much biotin (31).

Various disease states besides the AMI can also cause serum troponin values to rise. Kalyon S (31) stated that other than AMI, non-coronary causes such as pulmonary embolism, myocarditis, pericarditis, sepsis, long-term exercise, heparin, and immunotherapy can result in elevated troponin levels in blood. In the study of Meyer et al. (32) an elevated level of cTnI was defined in $40 \%$ of patients with pulmonary embolism.

In the review article written by Lum et al. (33) reasons such as fibrin interaction, high level of alkaline phosphatase (ALP), and the interaction of immunocomplex formation were given to cause false troponin positivity. Bohner et al. (34) documented the first false troponin negativity with their study in 1996, they found that the reason for this was immunoglobulin $G$ (IgG), which is an analyte-binding antibody and prevents cTnI recognition.

\section{High Sensitivity Cardiac Troponins (hs-cTn)}

Most of the clinics choose to use 5th generation hs-cTnT and hs-cTnI analysis rather than traditional cTn tests. These tests can demonstrate 10-100 times lower concentrations of troponin. For a patient who has come to the emergency room, the negative predictive hs-cTn value is $>95 \%$ to eliminate the diagnosis of AMI. When the test is repeated after 3 hours, this rate can increase up to $100 \%$ (35).

Although these tests have high specificity, they cannot determine necrosis etiology alone. In addition, industrial standardization of hs-cTn tests has not been implemented yet. Therefore, there are difficulties in comparing them among medical systems (36).

\section{Evaluation of Results}

The one-hour "rule-in" and "rule-out" algorithms are used in patients who come to the emergency department with non-ST elevation MI (NSTEMI). As 0-1 hour refers to the time when the blood test was first performed; whether the test verifies the MI or not depends on the type of the troponin used in the test kit. There are many test kits that use this algorithm (37):
The high sensitivity cardiac troponin T-test is a high sensitivity immunological test that is used for the determination of cTnT in human serum and plasma. If the cTnT level in the blood sample at 0th hour is less than $12 \mathrm{ng} / \mathrm{L}$ and the difference between the samples between 0 th- 1 st hours is $<5 \mathrm{ng} / \mathrm{L}, \mathrm{MI}$ is excluded. If the cTnT value of the blood sample at the 0 th hour is $\geq 52$ $\mathrm{ng} / \mathrm{L}$ and the difference between the samples between the 0 th-1 st hours is $\geq 5 \mathrm{ng} / \mathrm{L}$, then $\mathrm{MI}$ is considered.

The high sensitivity cardiac troponin I test is a highly sensitivity test used for the determination of the cTnI in serum. If the cTnI value in the blood sample at the 0th hour is $<5 \mathrm{ng} / \mathrm{L}$ and the difference between the blood samples between 0th-1 st hours is $<2 \mathrm{ng} / \mathrm{L}$, MI is excluded. If the value of the cTnI in the blood sample at 0 th hour is $\geq 52 \mathrm{ng} / \mathrm{L}$, and the difference between the value of samples between 0 th and 1 st hour is $\geq 6 \mathrm{ng} / \mathrm{L}$, then the possibility of MI is considered.

For a patient who has chest pain for more than 3 hours; if the cTnT level for the hs-cTnT test is $5 \mathrm{ng} / \mathrm{L}$, and the cTnI value for hs-cTnI test is $<2 \mathrm{ng} / \mathrm{L}$ in the sample serum which is immediately taken, the possibility of NSTEMI is excluded.

\section{SERUM CARDIAC TROPONIN ELEVATION OBSERVED IN OTHER DISEASES AND THEIR ROLE IN DIFFERENTIAL DIAGNOSIS}

The most common reason that may increase the serum cTn levels is ischemic necrosis due to perfusion-restricted or blocked mural or occlusive thrombus in the coronary artery. However, high cTn concentration in the blood can be a sign of ischemic and/or non-ischemic myocardial damage. These damages may also be the result of the non-atherothrombotic events; such as mechanical cardiomyocyte disorders due to myocardial damage, the cumulative effect of potential cardiotoxic drugs, bacterial toxins, or a neurohumoral reaction (1).

Elevated cTnI levels indicate cardiac damage, but it is insufficient to explain the cause of the damage. Increases in cTn levels can be observed in many different disease states and do not necessarily indicate AMI (5). Other causes include cardiac muscle inflammation, various etiologies to cause circulatory failure (e.g. following polytrauma, multiple organ failure associated with sepsis, severe burn, etc.), systemic hypotension that can lead to myocardial ischemia, and renal failure which may result in increased levels of cTn (especially 
cTnT) without any signs of infarction. Poisoning can also be counted among the causes. Carbon monoxide poisoning is quite common, and the decrease in the oxygen-carrying capacity of hemoglobin may cause myocardial hypoxia and increase in cTn (1).

Sometimes, prognostically, there may be elevated cTn concentrations owing to myocardial damage of iatrogenic origin following diagnostic or therapeutic procedures associated with coronary vessel catheterization and all cardiovascular procedures (1).

In the differential diagnosis, it may be difficult to interpret the serum cTn elevations in cases such as stroke, chronic obstructive pulmonary disease (COPD), pulmonary embolism, sepsis, exercise, acute perimyocarditis, Takotsubo cardiomyopathy (TC), acute heart failure, hypovolemia, renal failure, and tachycardia. The basic treatment strategy of these patients with increased cTn levels and various non-acute coronary syndromes is to eliminate the factors that cause an increase in cTn levels (5).

\section{Chronic Renal Failure}

Increases in cTn may be an indicator of poor prognosis in end-stage renal failure. It has been shown by several animal experiments that trauma and stress induce cTn in striated muscle (38). It is assumed that chronic striated muscle deformation and inflammation in dialysis patients induce cTn with a similar mechanism. Heart failure is a frequent comorbidity seen in renal failure in which elevated cTn levels occur without signs of ischemia or infarction (38).

In addition, decreased renal clearance level due to renal failure is another reason that may cause elevated cTn levels. In the presence of renal failure in a patient, the removal of cTn from the body is interrupted by the routine loss of myocytes. In these patients, increases in cTnT levels are observed more commonly than increases in cTnI levels due to differences in the elimination of cTnI and cTnT from the body (38).

\section{Chronic Obstructive Pulmonary Disease (COPD)}

Cardiovascular risk factors and cardiac comorbidity are conditions that are frequently observed in individuals with COPD. The more negative intrathoracic pressure results in increased left ventricular afterload. Increased pulmonary tension, hypoxia, and hypercapnia cause cardiac muscle deformations during acute exacerbation (38). Neukamm et al. (39) observed that stable COPD was independently associated with high- er hs-cTnT levels in peripheral blood when randomly drawn individuals from the general population was compared with COPD patients in a stable state. In individuals with stable COPD, increased levels of hs-cT$\mathrm{nT}$ have been proven to be associated with immune activation and the degree of the disease. In addition, a positive correlation was found between neutrophil and serum cTn levels in COPD patients. On this account, it can be said that the excessive inflammatory response in COPD exacerbations causes damage to the heart muscle (40). It is demonstrated that increased cTnT level during COPD exacerbation is associated with increased mortality rates in the first year following discharge (39).

\section{Strenuous Exercise}

Both intense and light exercise can be misleading if the patient is suspected of MI due to high troponin levels (41). Physicians should be well informed about the exercise-induced cTn elevation and carefully evaluate the patient in terms of exercise history before diagnosing MI (42).

Studies have shown that myocardial demand, which increases in parallel with endurance exercise, can physiologically increase the turnover rate of cTns. Another possibility is the accumulation of stress-induced free radicals, which causes an inconsistent increase in myocyte membrane permeability and can cause troponin leakage from the cell cytosol (38).

However the mechanism works, there are many differences between the kinetics of asymptomatic cTn release after intensive exercise and the kinetics of the increase in serum cTn levels in ACS. Early peaking and rapid return to normal characteristics can be shown as examples (38). Exercise time, difficulty, and working distance are variables that affect the cTn increase, however, it has been shown that even short distance work/ workout can cause serious cTn release in untrained people. Considering the available information, there is no prognostic effect of increased cTn level (38).

\section{Takotsubo Cardiomyopathy}

Takotsubo Cardiomyopathy (TC) is a disease that develops due to left ventricular dysfunction as a result of severe emotional or physical stress (43). Stress-induced TC shows similarities with ACS in ECG measurements and elevated cardiac enzyme levels. Therefore, the diagnosis of this syndrome depends on the exclusion of ACS (44). Cardiac troponin increases in 
$90 \%$ of patients who have TC. However, these increases are lower than the increase we observe in ST-segment elevation myocardial infarction (STEMI). The exact mechanism for the coordinated cTn increase in this syndrome is unknown. The possible mechanisms are demonstrated as; multi-vessel coronary artery spasm, ACS with reperfusion damage, impaired cardiac microvascular function, impaired myocardial fatty acid metabolism, and myocardial micro-infarction caused by endogenous catecholamines (15).

\section{Sepsis and Septic Shock}

Sepsis is seen as one of the most common causes of mortality in intensive care units. Organ dysfunction and multi-organ failure characterized by sepsis are encountered as well (45).

A decrease in ventricular performance is observed in approximately $50 \%$ of the cases with severe sepsis and septic shock (38). In addition, a significant relationship was found between sepsis, low cardiac function, and high stroke volume (46). Otherwise, $43-85 \%$ of patients who receive sepsis or systemic inflammatory response syndrome treatment in the intensive care units of hospitals have increased cTn values. Many studies prove that this increase in serum cTn levels is associated with mortality in sepsis cases (38). The mechanism of sepsis and its accompanying cTn increase is still not fully proven, but there are many theories about it. One of the accepted theories is based on the assumption of myocardial ischemia. According to this theory, increased oxygen demand in the myocardium is related to fever and tachycardia commonly observed in sepsis (38). Additionally, respiratory failure, hypotension, microcirculation dysfunction, and occasional systemic hypoxemia caused by anemia can result in a decreased amount of available oxygen to the myocardium. The myocardium releases cTn by being damaged due to mismatched supply and demand for oxygen (38). Apart from this theory, there are also theories explaining the increase in cTn level in sepsis with myocardial damage and myotoxic effect resulted from reactive oxygen radicals produced by endothelial cells, macrophages, and effective neutrophils triggered by inflammation (38).

\section{OTHER BIOCHEMICAL PARAMETERS FOR DETERMINING AMI}

Although cTns, which are indicatives of myocardial ischemia, are used as the main biochemical markers, the increase in cTns in some other diseases can be mis- leading in terms of AMI diagnosis (5, 38-46). However, it should not be forgotten that besides cTns, other plasma markers can also be used in the diagnosis of AMI (47).

Electrocardiogram (ECG) will be the first diagnostic procedure to be performed for the patient with suspected MI, however, ECG is not sufficient for diagnosis of MI since ECG changes may not be observed in all patients having MI. In addition to the ECG, cardiac markers should also be checked (47).

An ideal marker should have high tissue specificity, be intense in tissue and rise rapidly in blood after damage. The time when it is high in blood should be also long enough for measurement. There must be a direct proportion between the extent of the damage and the concentration of the marker in the blood. Its quantitative measurement can be made and it should not cost too much (48).

Creatine kinase (CK), CK-MB, aspartate aminotransferase (AST), lactate dehydrogenase (LDH), myoglobin, and troponins are some markers that can be examined in plasma for MI (Table 3) (47-49).

Myoglobin is the first cardiac biomarker to appear in the blood after MI. It starts to rise in 2-4 hours, peaks in 12-24 hours, and declines within 7-10 days (50).

Troponins start to rise in blood subsequent to the myoglobin. It rises in 4-6 hours, peaks in 12-24 hours, and declines within 7-10 days. Cytosolic troponins are released relatively earlier compared to the troponins found in the contractile structure. The stage of the damage can be determined by assessing the levels of the different troponin variants (50).

Following the troponins, total CK rises in 4-6 hours, peaks in 24-48 hours, and declines within 2-4 days. Aspartate aminotransferase (AST) rises in 6-8 hours, peaks in 24-48 hours, and declines within 4-6 days.

Finally, LDH rises in 12-24 hours, peaks at 48-72 hours, and declines within 12-14 days (50).

Knowing these values tells us at what time to look at which indicator and shows when to do the next test. If the marker remains high in the blood for a long time, it is important to evaluate the risk of subsequent infarction. It is difficult to diagnose a subacute infarction by markers with a short half-life (48).

Although AST has a high sensitivity in infarction, it is not specific for cardiac tissue. In cases such as hepatic congestion secondary to heart failure, myocarditis, post-cardioversion, pericarditis, etc., AST levels may be elevated in the blood (49).

Lactate dehydrogenase is a cardiac enzyme with 5 isoenzymes. LDH-1 mainly exists in cardiac myocytes and erythrocytes (51). The level of LDH-2 in the blood 
Table 3: MI markers and the chronological history (49).

Name of the marker

$A S T$

$L D H$

1950 s

1960s

$C K$

$C K-M B$

$c T n$
The years it started to

be used

\section{Limitations}

It has less specificity for myocardial tissue.

It has less specificity for myocardial tissue.

Because it is also found in the skeletal muscle, it is found in high levels in the blood in other diseases.

1. Low specificity for cardiac injury.

2. It cannot be used for late diagnosis due to its early release into the blood.
Although it is specific to myocardial necrosis, it cannot differentiate ischemic myocardial injuries from nonischemic myocardial injuries.

AST: Aspartate aminotransferase LDH: Lactate dehydrogenase CK: Creatine kinase CK-MB: Creatine kinase muscle and brain cTn: Cardiac troponin. 
of a healthy individual is higher than the LDH-1 isoenzyme, however, this rate varies in favor of LDH-1 in MI. This is also referred to as the "flipped LDH pattern phenomenon". Nonetheless, since LDH-1 is also high in erythrocytes, this phenomenon may occur outside of MI due to an event that may cause hemolysis (e.g. many diseases such as hemolytic anemia, pancreatitis) (52).

Myoglobin is found in the skeletal muscle and cardiac tissue. The advantage of myoglobin is that it is released earlier than other markers, through its low molecular weight. In this way, early diagnosis can be provided in the presence of AMI (53). The biggest disadvantage is that it is not specific to the heart tissue due to its abundance in the skeletal-muscular system. A number of studies in the literature stated that it can only show $90 \%$ sensitivity in AMI $(53,54)$.

Creatine kinase (CK) has 3 isoenzymes: $\mathrm{MB}, \mathrm{BB}$ and MM. Similar to myoglobin, CK is also found in many tissues other than cardiac muscle tissue, especially in skeletal muscle tissue. That's why high levels of CK does not necessarily indicate cardiac tissue necrosis (53). The success rate in the diagnosis of infarction can be increased by calculating the $\mathrm{CK}-\mathrm{MB} /$ Total $\mathrm{CK}$ ratio (55). Cardiac troponins are more sensitive and specific in the diagnosis of $\mathrm{MI}$ than $\mathrm{CK}-\mathrm{MB}$, which was formerly known as a gold-sensitive cardiac marker (3). However, since troponin serum levels begin to fall over the next 4-10 days down to normal levels; CK-MB is still used in the diagnosis of reinfarction (56).

Troponins have been found more successful than CK-MB in determining extensive infarction (55). In addition, increased troponin levels may be informative in terms of the risk of adverse cardiac events (53).

As a result, cardiac troponins are markers with high specificity and high sensitivity. The measurement of troponin in the blood has a dual role: Abnormally high concentrations indicate AMI, whereas mildly elevated troponin levels with chest pain indicate 5 times higher risk for a cardiac event over the next 4-6 weeks (3).

In patients without ST elevation, the baseline cTnI levels correlate with 6-week mortality. For this reason, troponin levels are monitored periodically after cardiac operations (57).

Parameters such as high sensitivity $\mathrm{C}$ reactive protein (hs-CRP), cardiac myosin light chain (MLC), D-Dimer, heart-type fatty acid binding protein (h-FABP), ischemia modified albumin (IMA), myeloperoxidase (MPO), glycogen phosphorylase isoenzyme $\mathrm{BB}$ (GP-BB), and carbonic anhydrase isoenzyme III (CA III) are other cardiac markers that can be found in the literature (51).

\section{THE IMPORTANCE OF POINT-OF-CARE TESTS IN AMI DIAGNOSIS}

Central laboratories are used to assess cTn concentrations as a regular method, but these laboratories can provide information with a one-hour recommended turnaround time (58). The use of rapid diagnostic tools is essential in the emergency departments and in ambulances notably for the acute coronary syndrome. Neumann et al. have shown that prevention of ischemic events that occur while waiting for the delayed procedure can be achieved by early intervention (59).

However, point-of-care (POC) cardiac troponin tests do not perform as good as hs-cTn tests and are not considered as troponin tests with high sensitivity (37). Tests provided by central laboratories are more sensitive than point-of-care cardiac troponin tests. Nonetheless, central laboratories are not available 24 hours a day and laboratories cannot be used in various settings such as ambulances and emergency rooms where rapid decision-making is crucial. In such cases, POC cTn tests provide results in 10 to 20 minutes by a shorter turnaround time for cardiac biomarker detection (60).

However, a Japanese study has shown that in order to use POC cTnI level for an ACS diagnosis, sampling should be performed more than 3 hours after the onset of symptoms (21). Similarly, in a guideline published by ESC in 2015, it is stated that POC cTn test has a low diagnostic sensitivity as a first-line analysis since it takes time for cTn to reach a significant detectable level (37).

Furthermore, the price of the tests should also be taken into account. Bingisser et al. (60) and the Canadian Agency for Drugs and Technologies in Health (CADTH) state that POC testing is not cost-effective compared to central laboratory testing (61).

\section{CONCLUSION}

Acute myocardial infarction develops when blood flow to the heart is blocked (16). Electrocardiographic changes, particular cardiac biomarkers indicating myocardial ischemia and ECHO can be used in the diagnosis of AMI. However, there are also patients without abnormal ECG, ECHO, or chest pain-like findings $(21,22)$. It should be kept in mind that the first ECG measured allows only $50 \%$ accurate diagnosis in AMI; therefore, markers indicating myocardial necrosis in such cases are among the most helpful agents for physicians to make an accurate diagnosis (19). 
Some markers examined in plasma for MI can be listed as CK, CK-MB, AST, LDH, myoglobin, and troponins (47). In the 1980s cTns which are more specific than other markers have been used (49). Cardiac troponins are more sensitive and specific indicators of myocardial damage than CK-MB and ECG $(6,7,55)$. Especially I and T isoforms are more specific to cardiac tissue and are used in the diagnosis of MI $(1,4)$.

Instead of the cTn tests, hs-cTnT and hs-cTnI analyses have started to take place in clinical routine. They show levels of troponin at 10-100 times lower concentration (35). Although hs-cTn tests have high specificity, they are insufficient in determining the etiology of necrosis alone. In addition, hs-cTn tests have not been industrialized yet (36). In cardiac troponin analysis, 0-1 hour "rule-out" and "rule-in" algorithms are used for patients with NSTEMI who come to the emergency room (37). In this way, AMI can be eliminated in the early period, the diagnosis of patients with AMI can be made in a shorter time, and the treatment is initiated.

Point-of-care tests are used as well as hs-cTn tests in the diagnosis of AMI (37). Point-of-care tests are required in places such as emergency rooms and healthcare transporters where the central laboratories are unavailable and rapid interventions are critical (59). Nevertheless, the convenience and the limitations of POC tests should be taken into account in the diagnosis of MI.

To conclude, owing to their high sensitivity and specificity, cardiac troponin levels alert the physicians to the ongoing and recent myocardial infarction and facilitate the early diagnosis of MI $(1,3,6,7,49)$. Thus, cardiac troponins are clinically crucial for the MI diagnosis.

\section{Ethics Committee Approval: N/A \\ Informed Consent: N/A}

Conflict of Interest: The authors declared no conflict of interest. Author contributions: Concept: YA Supervision: BK, YA Resources: BK, BE, DYG, GA, OB, PA, SK, YA Materials: BK, BE, DYG, GA, $\mathrm{OB}, \mathrm{PA}, \mathrm{SK}$, YA Data collection and/or processing: BK, BE, DYG, GA, OB, PA, SK, YA Analysis and/or Interpretation: BK, BE, DYG, GA, OB, PA, SK, YA Literature Search: BK, BE, DYG, GA, OB, PA, SK, YA Writing Manuscript: BK, BE, DYG, GA, OB, PA, SK, YA Critical Review: BK, YA

Financial disclosure: The authors declared that this study received no financial support.

Editor in chief's Note: One of the authors of this article, Berra Kurtoğlu is a member of the editorial board of Turkish Medical Student Journal. However, she did not take place in any stage of the editorial decision of the manuscript. The editors who evaluated this manuscript are from other institutions.

\section{REFERENCES}

1. Racek J, Rajdl D, editors. Clinical Biochemistry. 1st ed. Prague: Karolinum Press; 2016.p.296-8.

2. Duygu E, Kahraman N, Pehlivanoğlu S et al. Akut koroner sendrom dışı olaylarda kardiyak troponin yüksekliğinin klinik önemi. Türk Kardiyoloji Dem Arş 2004;32:571-80.

3. Peela JR, Jarari AM, Hai A et al. Cardiac biomarkers: the troponins and CK-MB. Ibnosina Journal of Medicine and Biomedical Sciences 2010;2(5):190-7.

4. Topol EJ. Chapter 13. In: Topol EJ, editor. Acute Coronary Syndromes. 3rd ed. Florida: CRC Press;2004.p.329-65.

5. Agewall S, Giannitsis E, Jernberg T et al. Troponin elevation in coronary vs. non-coronary disease. Eur Heart J 2011;32(4):404-11. 6. Alpert JS, Thygesen K, Antman E et al. Myocardial infarction redefined-a consensus document of The Joint European Society of Cardiology/American College of Cardiology Committee for the redefinition of myocardial infarction. J Am Coll Cardiol 2000;36:95969.

7. Kavsak PA, MacRae AR, Lustig et al. The impact of the ESC/ACC redefinition of myocardial infarction and new sensitive troponin assays on the frequency of acute myocardial infarction. Am Heart J 2006;152:118-25.

8. Braunwald E, Antman EM, Beasley JW et al. ACC/AHA 2002 guideline update for the management of patients with unstable angina and non-ST-segment elevation myocardial infarction-summary article: a report of the American College of Cardiology/American Heart Association task force on practice guidelines (committee on the management of patients with unstable angina). J Am Coll Cardiol 2002;40:1366-74.

9. Bassand JP, Hamm CW, Ardissino D et al. Guidelines for the diagnosis and treatment of non-ST-segment elevation acute coronary syndromes. Task Force for Diagnosis and Treatment of Non-STSegment Elevation Acute Coronary Syndromes of European Society of Cardiology. Eur Heart J 2007;28:1598-660.

10. Celebi OO, Diker E, Aydogdu S. Kardiyak troponinlerin klinik önemi. Turk Kardiyol Dern Ars 2008 Jun;36(4):269-77.

11. Sheehan P, Vasikaran SD. The evolving clinical role of cardiac troponins and new acute myocardial infarction guidelines: implications for the clinical laboratory. Clin Bichemist Rev 2001;23:52-65. 12. Wu AHB. Increased troponin in patients with sepsis and septic shock: myocardial necrosis or reversible myocardial depression? Intensive Care Med 2001;27:959-61.

13. Morrow DA, Rifai N, Tanasijevic MJ et al. Clinical efficacy of three assays for cardiac troponin I for risk stratification in acute coronary syndromes: a Thrombolysis In Myocardial Infarction (TIMI) 11B Substudy. Clin Chem 2000 Apr;46(4):453-60.

14. Šimić S, Svaguša T, Prkačin I et al. Relationship between hemoglobin A1c and serum troponin in patients with diabetes and cardiovascular events. Journal of Diabetes and Metabolic Disorders 2019;18(2):693-704.

15. Akwe J, Halford B, Kim E et al. A review of cardiac and non-cardiac causes of troponin elevation and clinical relevance part I: cardiac causes. J Cardiol Curr Res 2017;10(2):00360.

16. Mayo Clinic. Heart attack. (serial online) (cited 2020 May 29). Available from: URL:https://www.mayoclinic.org/diseases-conditions/heart-attack/symptoms-causes/syc-20373106.

17. T.C. Sağlık Bakanlığı Halk Sağlığı Genel Müdürlüğü Kronik Hastalıklar ve Yaşlı Sağlığı Dairesi Başkanlığı. Kalp damar hastalıkları kalp krizi (serial online) (cited 2020 May 29). Available from:URL: https://hsgm.saglik.gov.tr/tr/kalp-damar-hastaliklari/ liste/kalp-damar-hastal\%C4\%B1klar\%C4\%B1-kalp-krizi.html. 18. Aykut K, Güzeloğlu M, Albayrak G et al. Akut koroner sendro- 
mun cerrahi tedavisi. Turkiye Klinikleri J Cardiol-Special Topics 2013;6(6):42-4.

19. Kekeç Z. Tüm yönleriyle acil tıp (tanı, tedavi ve uygulama kitab1). 3rd ed. Ankara: Akademisyen Tip Kitabevi; 2013.p.69-88.

20. Thygesen K, Alpert JS, Jaffe AS et al. Third universal definition of myocardial infarction. J Am Coll Cardiol 2012;60:1581-98.

21. Suzuki K, Komukai K, Nakata K et al. The usefulness and limitations of point-of-care cardiac troponin measurement in the emergency department. Intern Med 2018;57(12):1673-80.

22. Thygesen K, Alpert JS, Jaffe AS et al. Third universal definition of myocardial infarction. Eur Heart J 2012;33(20):2551-67.

23. Upasham S, Tanak A, Prasad S. Cardiac troponin biosensors: where are we now? Advanced Health Care Technologies 2018;4:113.

24. Shah AS, Anand A, Sandoval Y et al. High-sensitivity cardiac troponin I at presentation in patients with suspected acute coronary syndrome: a cohort study. Lancet 2015;386(10012):2481-8.

25. Christenson RH, Azzazy HME. Cardiac point of care testing: a focused review of current National Academy of Clinical Biochemistry guidelines and measurement platforms. Clin Biochem 2009;42(3):150-7.

26. Bertsch T, Bleuel H, Deschl U et al. A new sensitive cardiac troponin $\mathrm{T}$ rapid test $\left(\mathrm{TROPT}^{\oplus}\right)$ for the detection of experimental acute myocardial damage in rats. Exp Toxicol Pathol 1999;51(6):565-9.

27. Avcıküçük M, Bakır F, Topçuoğlu C et al. Akut koroner sendromda troponin $\mathrm{T}$ ve troponin I. Turk Hij Den Biyol Derg 2011;68(3):127-34.

28. Pagani F, Bonetti G, Panteghini M. Comparative study of cardiac troponin I and T measurements in a routine extra-cardiological clinical setting. J Clin Lab Analy 2001;15:210-4.

29. Elmalı E, Karaören Z, Özdöl C et al. Akut koroner sendromlu hastalarda kardiyak troponin T ve troponin I'nın karşılaştırılması. Turk J Biochem 2005;30(3):212-5.

30. Ross G, Bever FN, Uddin Z et al. Troponin I sensitivity and specificity for the diagnosis of acute myocardial infarction. J Am Osteopath Assoc 2000;100(1):29-32.

31. Kalyon S. Yanlış troponin pozitifliği. Dirim Tip Gazetesi 2010;85:29-31.

32. Meyer T, Binder L, Hruska N et al. Cardiac troponin I elevation in acute pulmonary embolism is associated with right ventricular dysfunction. J Am Coll Cardiol 2000;36(5):1632-6.

33. Lum G, Solarz DE, Farney L. False positive cardiac troponin results in patients without acute myocardial infarction. Laboratory Medicine 2006;37(9):546-50.

34. Bohner J, von Pape KW, Hannes W et al. False-negative immunoassay results for cardiac troponin I probably due to circulating troponin I autoantibodies. Clin Chem 1996;42(12):2046.

35. Garg P, Morris P, Fazlanie AL et al. Cardiac biomarkers of acute coronary syndrome: from history to high-sensitivity cardiac troponin. Intern Emerg Med 2017;12(2):147-55.

36. Sherwood MW, Kristin Newby L. High-sensitivity troponin assays: evidence, indications, and reasonable use. J Am Heart Assoc 2014;3(1):e000403.

37. Roffi M, Patrono C, Collet JP et al. 2015 ESC guidelines for the management of acute coronary syndromes in patients presenting without persistent ST-segment elevation: ask force for the management of acute coronary syndromes in patients presenting without persistent ST-segment elevation of the European Society of Cardiology (ESC). Eur Heart J 2016;37:267-315.

38. Tanindi A, Cemri M. Troponin elevation in conditions other than acute coronary syndromes. Vasc Health Risk Manag
2011;7:597-603.

39. Neukamm AM, Høiseth AD, Hagve TA et al. High-sensitivity cardiac troponin T levels are increased in stable COPD. Heart 2013;99(6):382-7.

40. Brekke PH, Omland T, Holmedal SH et al. Determinants of cardiac troponin T elevation in COPD exacerbation - a cross-sectional study. BMC Pulm Med 2009:19;9-35.

41. Gresslien T, Agewall S. Troponin and exercise. Int J Cardiol 2016;221:609-21.

42. Shave R, Baggish A, George K et al. Exercise-induced cardiac troponin elevation: evidence, mechanisms, and implications. J Am Coll Cardiol 2010;56(3):169-76.

43. Harvard Health Publishing. Takotsubo cardiomyopathy (broken-heart syndrome). (serial online) (cited 2020 May 29). Available from: URL:https://www.health.harvard.edu/heart-health/takotsubo-cardiomyopathy-broken-heart-syndrome.

44. Ramaraj R, Sorrell VL, Movahed MR. Levels of troponin release can aid in the early exclusion of stress-induced (takotsubo) cardiomyopathy. Exp Clin Cardiol 2009;14(1):6-8.

45. Spies C, Haude V, Fitzner R et al. Serum cardiac troponin T as a prognostic marker in early sepsis. Chest 1998;113(4):1055-63.

46. Su WL, Shui HA, Lan CC et al. Cardiovascular parameters associated with troponin I as indicators for 14-day mortality in patients with septic shock. Am J Med Sci 2018;356(3):244-53.

47. Marshall WJ, Lapsey M, Day A et al. Lipids, lipoproteins and cardiovascular disease. Clinical Chemistry. 9th ed. St Louis: Elsevier; 2020.p.318-9.

48. Ulakoğlu Zengin E. Kardiyak acillerde biyokimya laboratuvarı. Hastalıkların Tanı ve İzlenmesinde Biyokimya Laboratuvarı Sempozyum Dizisi;81:49-66.

49. Danese E, Montagnana M. An historical approach to the diagnostic biomarkers of acute coronary syndrome. Ann Transl Med 2016;4(10):194.

50. Crook MA. Cardiovascular disease. In: Crook MA, editor. Clinical Biochemistry and Metabolic Medicine. London: CRC Press; 2012.p.326-8.

51. Dasgupta A, Wahed A. Cardiac Biomarkers. In: Dasgupta A, Wahed A, editors. Clinical Chemistry, Immunology and Laboratory Quality Control. St Louis: Elsevier; 2014.p.138-9.

52. Weinberger I, Rotenberg Z, Sagie A et al. "Flipped" lactic dehydrogenase pattern in acute coronary insufficiency. Clin Cardiol 1986;9(12):597-9.

53. Pant S, Deshmukh A, Neupane P et al. Cardiac biomarkers. Novel Strategies in Ischemic Heart Disease. IntechOpen (serial online) 2011 May-Sep (cited 2020 June). Available from: URL:https://www. intechopen.com/books/novel-strategies-in-ischemic-heart-disease/biomarkers-in-ischemic-heart-disease.

54. de Winter RJ, Lijmer JG, Koster RW et al. Diagnostic accuracy of myoglobin concentration for the early diagnosis of acute myocardial infarction. Ann Emerg Med 2000;35(2):113-20.

55. Babuin L, Jaffe AS. Troponin: the biomarker of choice for the detection of cardiac injury CMAJ 2005;173(10):1191-1202.

56. Raffel CO, White HD. Acute coronary syndromes. In: Sidebotham D, McKee A, Gillham M, editors. Cardiothoracic Critical Care. Oxford: Butterworth-Heinemann; 2007.p.257-77.

57. Habif S. Kardiyak troponinler. Türkiye Klinikleri J Med Sci 2003;23(1):74-80.

58. The American Association for Clinical Chemistry. Laboratory medicine practice guidelines: biomarkers of acute coronary syndromes and heart failure. (serial online) (cited 2020 May 21). Available from: URL:https://www.aacc.org/-/media/Files/Science-and-Practice/Practice-Guidelines/ACS-and-Heart-Failure/ 
ACS_PDF_online.pdf?la=en\&hash=735F26B3C58FD8539A2EC6A8A45351E9890FFFD3.

59. Neumann F, Kastrati A, Pogatsa-Murray G et al. Evaluation of rolonged antithrombotic pretreatment ("Cooling-Off" Strategy) before intervention in patients with unstable coronary syndromes: a randomized controlled trial. JAMA 2003;290(12):1593-9.

60. Bingisser R, Cairns C, Christ M et al. Cardiac troponin: a critical review of the case for point-of-care testing in the ED. Am J Emerg Med 2012;30(8):1639-49.

61. Ho C, Cimon K, Weeks L et al. Point-of-care troponin testing in patients with symptoms suggestive of acute coronary syndrome: a health technology assessment. Canadian Agency for Drugs and Technologies in Health (serial online) 2016 Mar (cited 2020 May 21). Available from: URL:https://www.ncbi.nlm.nih.gov/books/ NBK362842/. 